\title{
Expert recommendations for biological treatment in patients with psoriasis
}

\author{
Nancy Podoswa-Ozerkovsky, ${ }^{1 *}$ Mario Amaya-Guerra, ${ }^{2}$ José F. Barba-Gómez, ${ }^{3}$ Lorena Estrada-Aguilar, ${ }^{4}$ \\ Minerva Gómez-Flores, ${ }^{5}$ Adriana L. Lopeztello-Santillan, ${ }^{6}$ César A. Maldonado-García, ${ }^{7}$ \\ Mónica I. Rivera-Gómez, ${ }^{8}$ Delfina G. Villanueva-Quintero ${ }^{9}$ and Gladys León-Dorantes ${ }^{10}$ \\ ${ }^{1}$ Dermatology Department, Regional General Hospital No. 1, Instituto Mexicano del Seguro Social, Mexico City; ${ }^{2}$ Dermatology Department, Health and

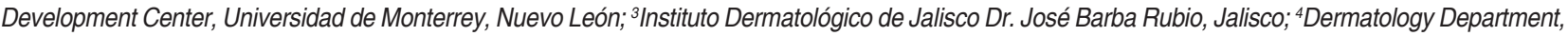 \\ Hospital Regional "Lic. Adolfo López Mateos", Instituto de Seguridad y Servicios Sociales de los Trabajadores del Estado, Mexico City; ${ }^{5}$ Dermatology \\ Department, University Hospital, Universidad Autónoma de Nuevo León, Nuevo León; ${ }^{6}$ Dermatology Department, Instituto de Seguridad Social del Estado \\ de México y Municipios, State of Mexico; 'Psoriasis Clinic Head Office, Centro Dermatológico "Dr. Ladislao de la Pascua", Mexico City; ${ }^{8}$ Dermatology \\ Department, Specialty Hospital, Centro Médico Nacional La Raza, Instituto Mexicano del Seguro Social, Mexico City; ${ }^{9}$ Clinical Research, Centro de \\ Atención en Enfermedades Inflamatorias, Jalisco; ${ }^{10}$ Unidad de Innovación Clínica y Epidemiológica del Estado de Guerrero, Guerrero. Mexico
}

\begin{abstract}
In recent years, the introduction of a series of biological drugs for the treatment of psoriasis has considerably increased the therapeutic armamentarium of doctors, and thus a strongly positive impact on the control of this condition has been achieved. With the purpose to provide the best recommendations for the use of these biological agents in patients with psoriasis, the Mexican group of psoriasis experts, PSOMEX, has developed recommendations in order to improve the understanding and therapeutic positioning of this type of medications.
\end{abstract}

KEY WORDS: Psoriasis. Psoriatic arthritis. Recommendations. Biological agents. Mexico.

\section{Recomendaciones de expertos para el tratamiento biológico en pacientes con psoriasis}

\section{Resumen}

En los últimos años, la introducción de diversos medicamentos biológicos para el tratamiento de la psoriasis ha aumentado considerablemente el arsenal terapéutico del médico, con lo cual se ha logrado un fuerte impacto positivo en el control de la enfermedad. Con el fin de proveer de las mejores recomendaciones para el uso de estos biológicos en los pacientes afectados de psoriasis, el grupo mexicano de expertos en psoriasis PSOMEX ha formulado recomendaciones para mejorar la comprensión y el posicionamiento terapéutico de este tipo de medicamentos.

PALABRAS CLAVE: Psoriasis. Artritis psoriásica. Recomendaciones. Agentes biológicos. México.

\section{Introduction}

Psoriasis is a chronic skin condition with a highly complex immune-mediated inflammatory basis. It is a common entity, with estimated prevalence rates between
1 and $4 \%$ in the world population and is associated with multiple comorbidities, significant deterioration of quality of life and social and economic functioning, as well as a reduction in life expectancy'.

In the last two decades, and as a result of the elucidation of several pathophysiological mechanisms

\section{Correspondence:}

*Nancy Podoswa-Ozerovsky

E-mail: npodoswa@yahoo.com.mx
Gac Med Mex. 2020;156:446-453

Contents available at PubMed

www.gacetamedicademexico.com

0016-3813/@ 2020 Academia Nacional de Medicina de México, A.C.. Published by Permanyer. This is an open access article under the CC BY-NC-ND license (http://creativecommons.org/licenses/by-nc-nd/4.0/). 
involved in the development of the disease, various biologic therapeutic agents have emerged, which have become the cornerstone in the treatment of patients with psoriasis. By 2013 , approximately $25 \%$ of patients with moderate to severe psoriasis in the world were already being treated with biological drugs $^{2,3}$.

\section{Objectives of the recommendations}

In order to develop practical recommendations that allow keeping the dermatologist updated in the field of optimal management of biological drugs, the group of experts of the Mexican group for the study of psoriasis and immune-mediated diseases (PSOMEX) gathered to develop said recommendations, which are based on the best available evidence, as well as on clinical experience of the group members.

\section{Method}

Multiple relevant questions concerning psoriasis biological treatment were defined. An extensive literature search was conducted in PubMed/Medline to identify case reports, case series, review articles, and clinical trials using the terms, "psoriasis" and "biologics". The review was limited to articles published in English and Spanish. The answers were formulated according to evidences found in said review and, in addition, included the experts individual experience. According to the Delphi method, voting was carried out to achieve a level of agreement regarding the answers, with consensus being defined when $70 \%$ of participants reached an agreement on the recommendation.

\section{Recommendations}

1. What is a biological drug and which ones are available?

The term "biological drug" refers to monoclonal antibodies and fusion proteins designed to selectively block biological molecules (cytokines, enzymes etc.).

Currently, the biological drugs available for the treatment of psoriasis and psoriatic arthritis are anti-TNF agents (infliximab, etanercept, adalimumab, certolizumab pegol and golimumab), anti-IL12/anti-IL23 agents (ustekinumab), anti-IL17 agents (ixekizumab, secukinumab, and brodalumab) and anti-IL23 agents (guselkumab, tildrakizumab and risankizumab (Table 1). ${ }^{4-10}$
Table 1. Biologic agents for the treatment of psoriasis

\begin{tabular}{l|l}
\hline Biologic agent type & Drug \\
\hline Anti-TNF & $\begin{array}{l}\text { Infliximab, etanercept, adalimumab, } \\
\text { certolizumab pegol, golimumab }\end{array}$ \\
\hline Anti-IL12/anti IL23 & Ustekinumab \\
\hline Anti-IL17 & Ixekizumab, secukinumab, brodalumab \\
\hline Anti-IL23 & Guselkumab, tildrakizumab, risankizumab
\end{tabular}

\section{Who is candidate for a biological drug?}

Patients with moderate to severe psoriasis in whom conventional systemic treatments have resulted in primary or secondary therapeutic failure or are contraindicated or not tolerated, are candidates for biological treatment, ${ }^{11}$ as well as patients with moderate to severe psoriasis classified as "high-need", where biological treatment can be indicated as first-line (Table 2).

3. Who indicates biological management?

Treatment should be indicated and supervised by dermatologists with experience in the diagnosis and treatment of psoriasis and with extensive knowledge on the management of biologic agents.

4. How to select the biologic agent?

The decision on which agent is appropriate to start with must be individualized, taking into consideration various factors (see pre-treatment evaluation). ${ }^{12,13}$

5. Absolute contraindications:

- Hypersensitivity to the drug.

- Serious active infections.

- Family or personal history of demyelinating disease contraindicates the use of anti-TNF agents.

- New York Heart Association class III or IV severe heart failure contraindicates the use of anti-TNF agents.

In case of family or personal history of inflammatory bowel disease, avoiding the use of anti-IL17 agents is suggested.

\section{Precautions for prescription}

Anti-TNF drugs should be prescribed with caution in patients with the following conditions:

- History of recurrent infections or previous serious infection.

- History of hematological diseases.

- New York Heart Association class I and II heart failure.

- Personal or family history of lupus.

- Pregnancy and lactation potential (see corresponding section). 
Table 2. Psoriasis severity categorization

\begin{tabular}{|c|c|c|c|c|}
\hline \multirow[t]{2}{*}{ Instrument } & \multicolumn{4}{|c|}{ Severity } \\
\hline & Mild & Moderate & Severe & High-need \\
\hline PASI & $0-5$ & $5-10$ & $>10$ & $\begin{array}{l}\text { - Involvement of high impact areas: } \\
\text { face, hands, feet and genitals. } \\
\text { - Presence of psoriatic arthropathy. } \\
\text { - Rapid generalization } \\
\text { - Resistance to treatments. } \\
\text { - Severe forms, erythroderma, pustular } \\
\text { forms. }\end{array}$ \\
\hline BSA & $<3 \%$ & $3-8 \%$ & $>10 \%$ & \\
\hline DLQI & $2-5$ & $6-10$ & $11-20$ & $21-30$ \\
\hline $\begin{array}{l}\text { PSSI } \\
\text { (Psoriasis Scalp } \\
\text { Severity Index) }\end{array}$ & $\begin{array}{l}<50 \% \text { of surface } \\
\text { involved, mild or } \\
\text { minimal erythema, } \\
\text { infiltration and } \\
\text { pruritus }\end{array}$ & $\begin{array}{c}<50 \% \text { of surface } \\
\text { involved, moderate } \\
\text { erythema, infiltration } \\
\text { and pruritus }\end{array}$ & $\begin{array}{l}>50 \% \text { of surface involved, } \\
\text { moderate or severe erythema, } \\
\text { infiltration, and pruritus, or presence } \\
\text { of scarring alopecia or involvement } \\
\text { in visible areas of the face }\end{array}$ & \\
\hline
\end{tabular}

\section{Pretreatment evaluation}

Before starting the patient on biologic agents, a patient baseline evaluation should be obtained with complete history and physical examination, with special attention to the psoriasis clinical form, previous treatments, present comorbidities (psoriatic arthritis and type of arthritis, history of neoplasms, chronic infections, lymphadenopathy, neurological, heart or autoimmune disease, etc.), preferences and availability for storage and application of the drug.

The patient should be broadly informed about the risks and benefits of the treatment, as well as the precautions to be taken during its administration. ${ }^{13,14}$

\section{Recommended laboratory and imaging tests}

The following studies are recommended for all patients prior to the start of biological treatment: ${ }^{14,15}$

- Complete blood count, complete metabolic panel including liver function tests, serology for human immunodeficiency virus, hepatitis $B$ and $C$, pregnancy test, purified protein derivative skin test (for tuberculosis detection), interferon gamma-release test and chest X-ray.

- Immunology panel (anti-nuclear, anti-DNA antibodies), which, although not strictly necessary, is recommended if there is a family history of lupus or in patients who develop symptoms or signs suggestive of lupus during treatment. Positivity alone is nonspecific and does not preclude treatment to be initiated in a patient.

\section{Vaccination}

Updating the vaccination schedule should be tried prior to initiating biological treatment; live attenuated virus or live virus vaccines should be avoided during biological treatment. The recommendation is no not vaccinate two weeks before starting treatment with biologic agents and waiting 6 months after discontinuing the biological to vaccinate (12 months for varicella zoster vaccine). Treatment can be reinitiated four weeks after vaccination. Inactivated virus vaccines can be applied during biological treatment, and applying influenza and pneumococcal vaccines during treatment is recommended. Live or live attenuated vaccines should neither be administered to newborns who have been exposed to biologic agents in utero; vaccination should be deferred for six months. ${ }^{16}$

10. Transition from systemic to biological or from biological to biological treatment

In the event of primary or secondary failure, transition can be carried out directly, even when overlapping with previous systemic or biological treatment. If the transition is required due to the development of an adverse event, starting the biological drug once the unwanted side effect has disappeared is recommended ${ }^{17-19}$.

\section{Monitoring during biological treatment and re-} sponse evaluation

During treatment, patients should be periodically evaluated to monitor treatment response, as well as possible development of complications. Patient assessment intervals are variable, but at least a quarterly evaluation is recommended.

Laboratory tests are recommended at intervals of three to six months or earlier, in case of exposure to 
risks or development of signs or symptoms suggestive of adverse effects. ${ }^{20-22}$.

12. Biological treatment optimization: dose increase, modification of administration intervals, combinations

In case of partial response or loss of effectiveness, first trying to optimize the treatment with the following strategies before switching to another biologic agent is always recommended:

- Increase the dose of the drug or shorten dosing intervals (Table 3).

- Combination with topical agents (topical steroids, vitamin $\mathrm{D}$ analogs, or keratolytic, reducer or retinoid agents), with phototherapy or with conventional systemic medications (methotrexate, cyclosporine for short periods).

- Eliminate or modify factors that contribute to loss of effectiveness: comorbidities, intercurrent infections, overweight, smoking, alcohol intake, and dietary factors. ${ }^{18,23-26}$

Combination of two or more biologic agents is not recommended

\section{Drug exchange (switching)}

Switching the drug is recommended when there is either primary or secondary therapeutic failure that does not respond to upgrading or when a drug-related adverse event develops. If this is done due to therapeutic failure, waiting a period to restart with a different biologic agent is not necessary; the usual dosing schedule (induction and maintenance dose) should be used. If the switch is related to the development of an adverse event, waiting until the event has resolved to restart with another biologic agent will be necessary.

The switch can occur between drugs of the same therapeutic group if required due to therapeutic failure. If the switch is driven by the development of adverse events considered as "class" effects, switching to a drug with another mechanism of action is advised. ${ }^{27}$

14. Intermittent treatment vs. continuous treatment In general, with biologic agents, intermittent or rotational treatments are not recommended.

15. When to discontinue biological therapy

- Primary failure: inability to achieve at least a reduction of $50 \%$ in the Psoriasis Area and Severity Index (PASI 50) in the time frames established for each drug.

- Secondary failure that does not respond to optimization strategies.

- Development of a serious adverse event.

- Elective major surgeries.
- Need for vaccination.

- Pregnancy (see corresponding section).

16. Treatment restart after discontinuation

Etanercept, adalimumab, ustekinumab, ixekizumab, secukinumab can be restarted with good response recapture.

Restarting with induction doses depends on the severity of the condition and the time elapsed since the last dose. It will be necessary considering it if more than three or four half-lives of the drug have elapsed since the last administration

It is not advisable to restart infliximab after prolonged interruptions (more than 12 weeks) due to a high risk of loss of effectiveness, as well as adverse reactions mediated by anti-drug antibodies. ${ }^{28-30}$

\section{Drug interactions}

Biological drugs can accelerate the metabolism of several drugs or increase their response; therefore, drug interactions should be monitored (Table 4).

\section{Biologic agents in special populations and situations}

\section{Pediatric age}

In children who are candidates for biological treatment, adalimumab can be used from four years of age on, etanercept from 6 years on and ustekinumab from 12 years on. ${ }^{31-34}$

\section{Geriatric population ( $>65$ years)}

Biological treatment is effective and safe in this population. There could be an increased risk of adverse effects such as infection, neoplasm or drug interactions. ${ }^{35}$

\section{Pregnancy, lactation, and reproductive potential}

Avoiding pregnancy during biological treatment is recommended.

There are no known interactions between biological treatments and contraceptive methods.

With pregnancy plans, discontinuing biologic agents for the following periods is recommended: etanercept, three weeks; infliximab, six weeks; adalimumab, six months; ustekinumab, 15 weeks. ${ }^{36}$

Should biological treatment be required during pregnancy, anti-TNF agents would be the first choice and, among them, certolizumab pegol as first-line, followed by etanercept. ${ }^{37}$

Discontinuing monoclonal antibodies in pregnant women at 16 weeks of gestation is recommended in order to avoid transplacental passage of antibodies.

Informing the pregnant patient on biological treatment about the "theoretical" risks of spontaneous 

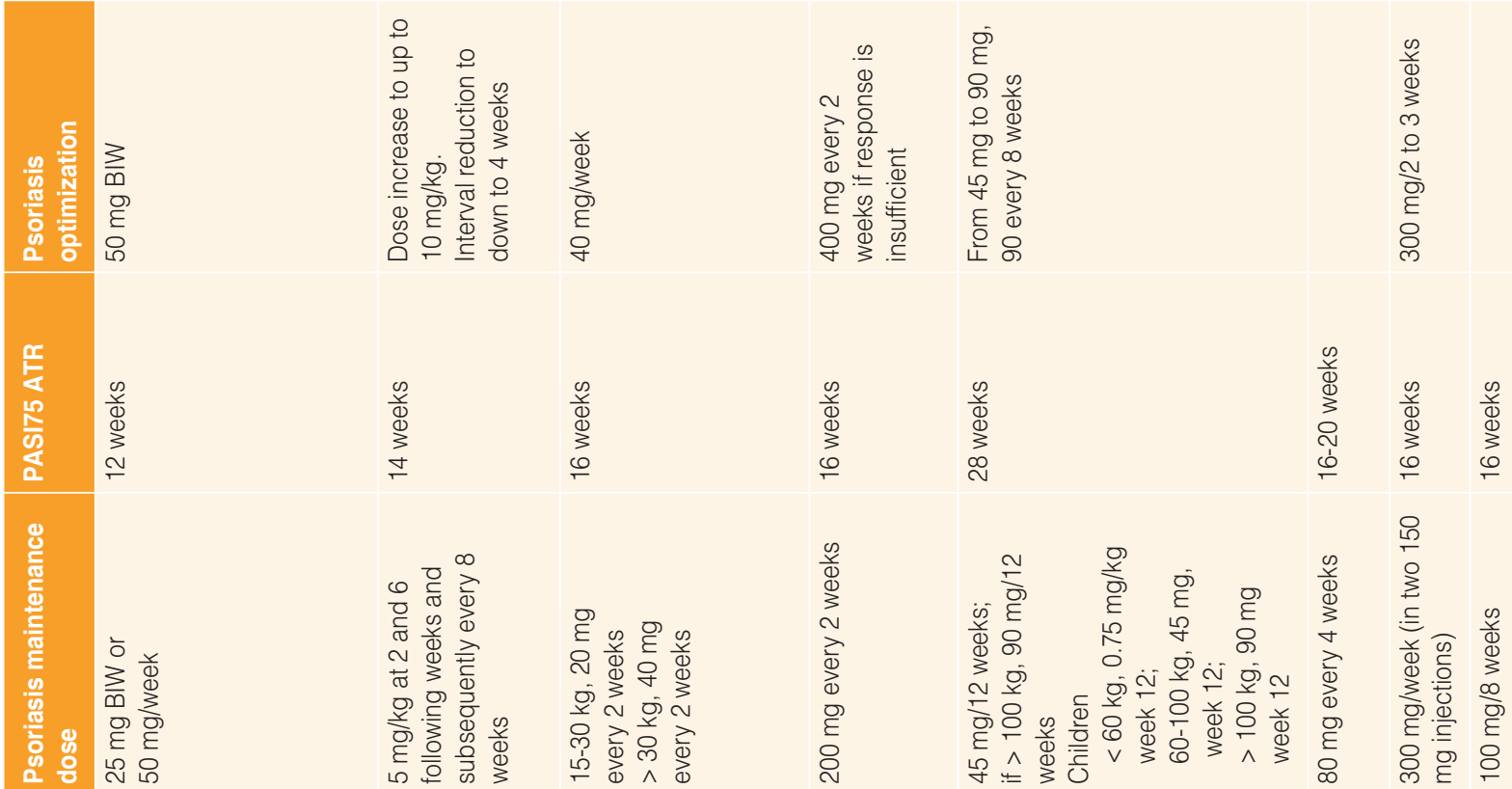

व)

$\sim$

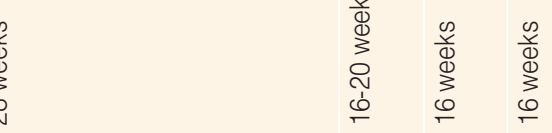

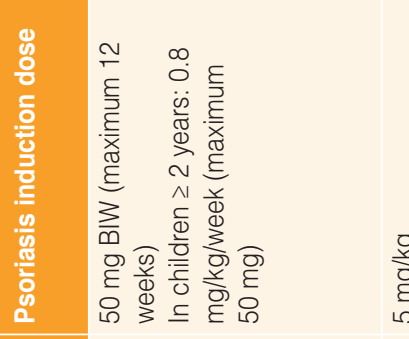

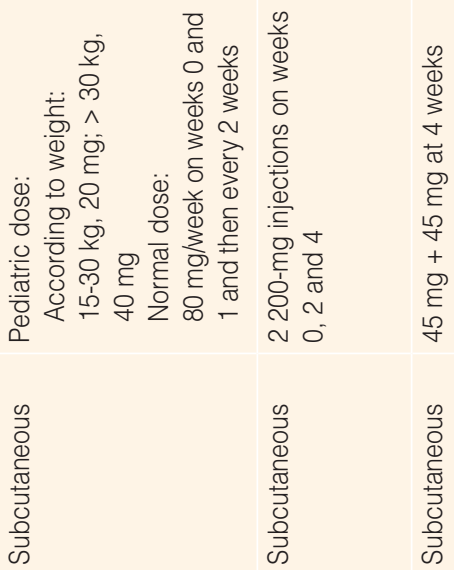

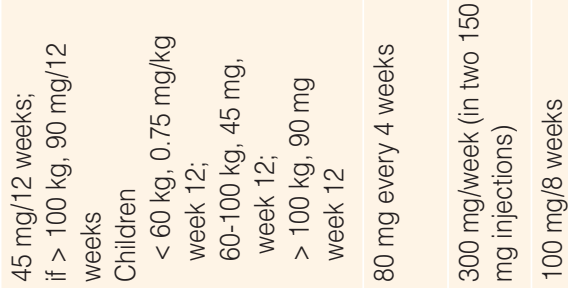

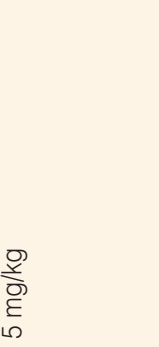

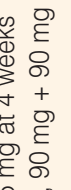

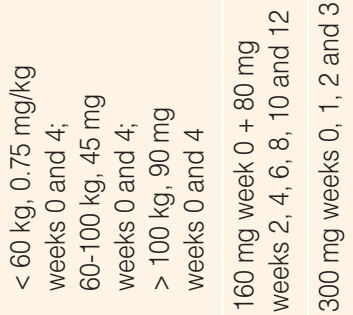

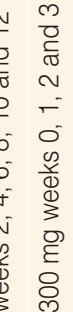
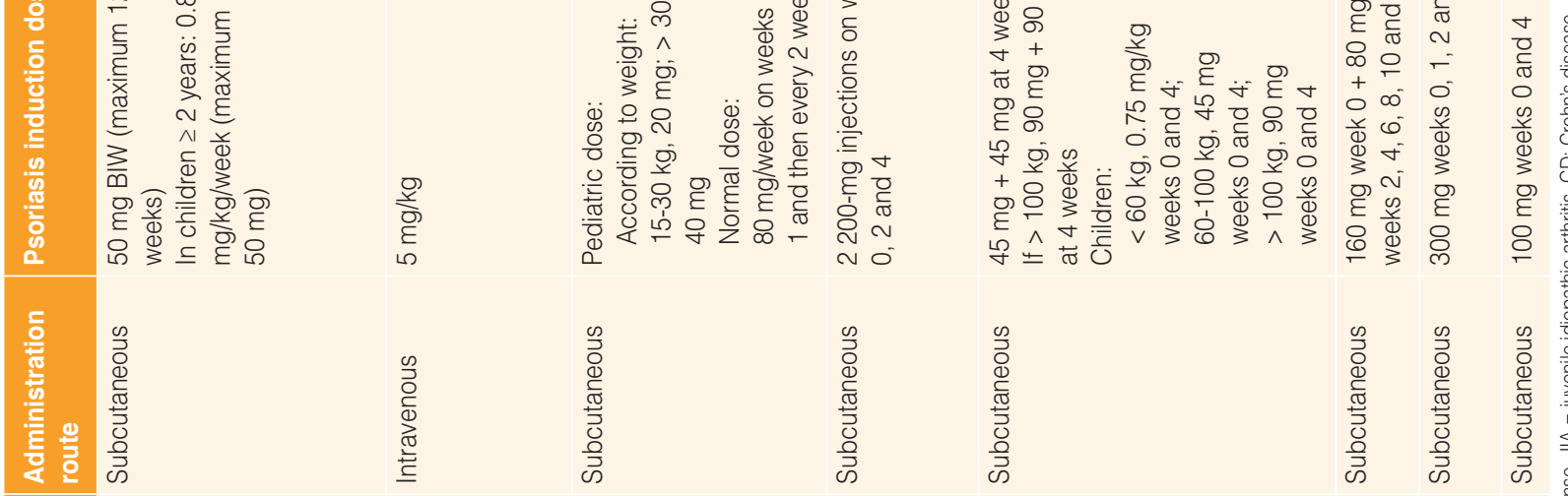

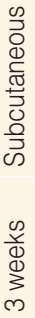

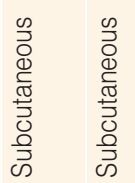

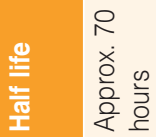

号

总

$\sim$

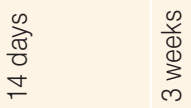

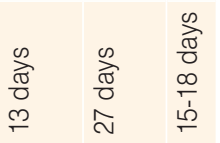

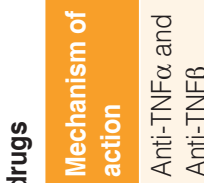

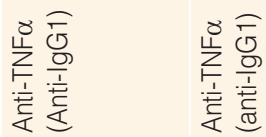

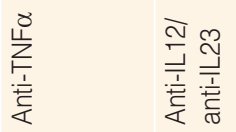

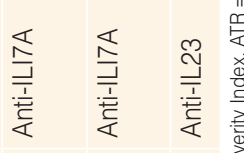

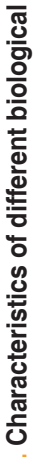

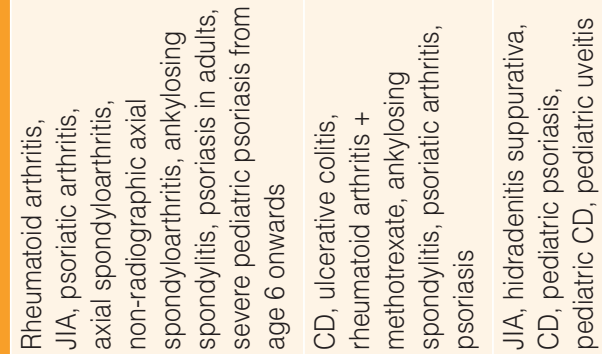
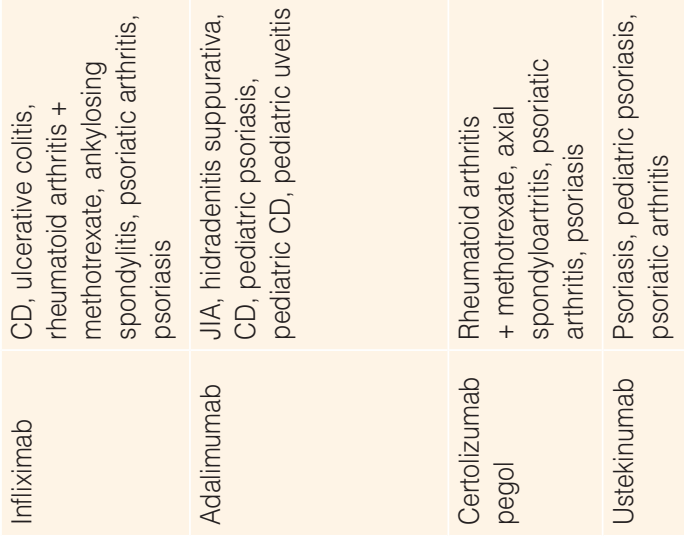

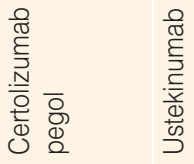

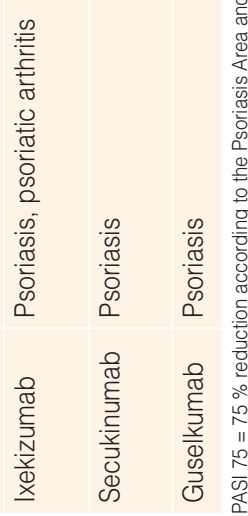


Table 4. Some of the major and minor interactions of the biologic agents used to treat psoriasis

\begin{tabular}{|c|c|c|}
\hline Drug & $\begin{array}{l}\text { Major interactions } \\
\text { (administering not recommended) }\end{array}$ & $\begin{array}{l}\text { Minor interactions } \\
\text { (monitoring recommended - may affect) }\end{array}$ \\
\hline Anti-TNF & $\begin{array}{l}\text { - Live virus vaccines } \\
\text { - Other biologic agent }\end{array}$ & $\begin{array}{l}\text { - Insulin and oral antidiabetic drugs (risk of hypoglycemia) } \\
\text { - Antihypertensive drugs (amlodipine, nimodipine) } \\
\text { - Statins (atorvastatin, simvastatin) } \\
\text { - Benzodiazepines (diazepam, alprazolam) } \\
\text { - Anticoagulants (warfarin) }\end{array}$ \\
\hline Anti-IL12/anti IL23 & $\begin{array}{l}\text { - Live virus vaccines } \\
\text { - Other biologic agent }\end{array}$ & $\begin{array}{l}\text { - Methylprednisolone } \\
\text { - Benzodiazepines (diazepam) } \\
\text { - Oral contraceptives (ethinyl estradiol, etonogestrel) } \\
\text { - Statins (lovastatin, atorvastatin) } \\
\text { - Antihypertensive drugs (nicardipine, nifedipine) } \\
\text { - Anticoagulants (warfarin) }\end{array}$ \\
\hline Anti-IL17 & $\begin{array}{l}\text { - Live virus vaccines } \\
\text { - Other biologic agent }\end{array}$ & $\begin{array}{l}\text { - Anti-arrhythmic drugs (amiodarone) } \\
\text { - Antihypertensive drugs (amlodipine, nicardipine) } \\
\text { - Benzodiazepine (clonazepam, diazepam) } \\
\text { - Oral contraceptives (drosperinone, norgestrel) } \\
\text { - Statins (simvastatin) } \\
\text { - Anti-HER2 (everolimus) } \\
\text { - Anticoagulants (warfarin) }\end{array}$ \\
\hline Anti-IL23 & $\begin{array}{l}\text { - Live virus vaccines } \\
\text { - Other biologic agent }\end{array}$ & $\begin{array}{l}\text { - Anti-arrhythmic drugs (amiodarone) } \\
\text { - Antihypertensive drugs (amlodipine, nicardipine) } \\
\text { - Anticoagulants (warfarin) } \\
\text { - Opioid analgesics (methadone) } \\
\text { - Benzodiazepine (clonazepam, diazepam) } \\
\text { - Oral contraceptives (ethinyl estradiol, etonogestrel) }\end{array}$ \\
\hline
\end{tabular}

abortions and immunosuppression in the newborn is necessary.

Breastfeeding is considered safe during treatment with anti-TNF drugs, and this safety profile can be applied to anti-IL17 and anti-IL23 agents. ${ }^{38}$

Male patients should be informed about the ability of anti-TNF agents to enhance fertilization capacity.

No alterations have been reported in the conception or development of fetuses resulting from fertilization by male patients under treatment with anti-TNF agents ${ }^{39,40}$.

4. Erythrodermic psoriasis

Infliximab is the biological drug of choice to treat rapidly progressive and unstable erythrodermic psoriasis. Using this agent as a rescue drug is not recommended. ${ }^{41}$

\section{Psoriatic arthritis}

Anti-TNF drugs are recommended as first-line agents in the treatment of patients with severe psoriatic arthritis with or without severe skin involvement. Anti-IL17 agents, followed by ustekinumab, are recommended as second line of treatment. Treatment should be carried out in consultation with the rheumatologist. ${ }^{42}$

6. Chronic viral diseases

- Human immunodeficiency virus (HIV). Biologic agents can be used in HIV-positive patients with moderate to severe psoriasis resistant to conventional systemic treatments, in combination with antiretroviral therapy (HAART). Using etanercept as first choice is suggested, although all anti-TNFs, ustekinumab, secukinumab and ixekizumab have been used with a good safety and efficacy profile. Treatment in close communication with the infectology department, and regular monitoring of viral load and for possible adverse effects is recommended. ${ }^{43}$

- Hepatitis $B$ and $C$. Before starting management with a biological drug, the specialist should be always consulted. Offering antiviral management before the start of treatment is recommended, and during its course, liver function should be monitored, as well as viral load.

Anti-TNF agents should be avoided in patients with hepatitis $B$ virus infection, given that they have been associated with infection reactivation; ustekinumab would be the agent of choice, with low risk of viral reactivation, followed by anti-IL17 and anti-IL23 agents.

Data of studies suggest that anti-TNF agents can be used in patients with hepatitis $C$ infection; in this regard, data on the use of ustekinumab are scarce and contradictory, and caution is therefore suggested. There are still no sufficient data regarding the use of anti-IL17 or anti-IL 23 agents in this context. ${ }^{44-49}$ 


\section{Latent tuberculosis}

Starting with ustekinumab or anti-IL17 agents is recommended in patients with latent tuberculosis who have completed at least one month of antifungal treatment. Etanercept is the anti-TNF agent with the lowest risk of reactivation ${ }^{50,51}$.

\section{Liver disease: steatohepatitits, cirrhosis}

Anti-TNF agents and ustekinumab can be used with caution and in close communication with the specialist. Data so far suggest that anti-IL17 agents could also be used, with a good safety profile. ${ }^{52,53}$

\section{Organ transplantation}

In general, using biological agents as third line is recommended in patients with transplants. Most these patients have been treated with etanercept, although there are already some reports of good response with a good safety profile with the use of ixekizumab ${ }^{54}$.

10. Biologic agents in surgery

In low-risk surgical procedures, it is considered that anti-TNF agents and ustekinumab don't have to be discontinued in case of post-surgical infection. In procedures with moderate to high risk of complications (infection or negative impact on wound healing), the decision to continue or not with biological treatment should be individualized considering the type of procedure, patient comorbidities, disease severity and risk of exacerbation after discontinuation of the biologic agent, as well as concomitant medication.

In case discontinuation of the biologic agent is required before the procedure, three to five half-lives should elapse prior to the procedure: with etanercept, two to three weeks; adalimumab, six to eight weeks; infliximab, four to six weeks; ustekinumab, 12 weeks.

There are insufficient data to make specific recommendations regarding the newer agents: anti-IL17, anti-IL23. ${ }^{55}$

\section{Biologic agents in hemodialysis}

Using of biologic agents as first line is recommended in patients with kidney disease and in those on hemodialysis (anti-IL17, ustekinumab and anti-TNF). ${ }^{56}$

\section{Biologic agents in cancer patients}

In general, biologic agents, including anti-TNFs, ustekinumab and anti-IL17 agents, are not contraindicated in patients with a personal history of solid, hematological, or non-melanoma and melanoma skin neoplasms. The decision to start treatment with any biologic agent in a patient should be individualized and always in coordination with the oncologist. ${ }^{57,58}$

13. Overweight and obesity

A negative effect of overweight on biological treatment has been demonstrated, except for infliximab, which is the only drug that is dosed per kilogram of body weight, and thus it is the medication of choice in patients with morbid obesity.

Dose increase or dosing interval shortening can be considered in obese patients who fail to respond to standard doses (see optimization). ${ }^{59}$

\section{Conflict of interests}

Dr. Podoswa has collaborated with Elly Lilly, Abbvie, Pfizer, Novartis and Janssen.

\section{Funding}

The meeting for the development of the recommendations article was held with the support of Eli Lilly $y$ Compañía de México S.A de C.V.

\section{Ethical disclosures}

Protection of human and animal subjects. The authors declare that no experiments were performed on humans or animals for this research.

Confidentiality of data. The authors declare that no patient data appear in this article.

Right to privacy and informed consent. The authors declare that no patient data appear in this article.

\section{References}

1. Gelfand JM, Troxel AB, Lewis JD, Kurd SK, Shin DB, Wang X, et al. The risk of mortality in patients with psoriasis: results from a population-based study. Arch Dermatol. 2007:143:1493-1499.

2. Parisi R, Symmons DP, Griffiths CE, Ashcroft DM, Identification and Management of Psoriasis and Associated ComorbidiTy (IMPACT) project team. Global epidemiology of psoriasis: a systematic review of incidence and prevalence. J Invest Dermatol. 2013;133:377-385

3. Yeung H, Takeshita J, Mehta NN, Kimmel SE, Ogdie A, Margolis DJ, et al. Psoriasis severity and the prevalence of major medical comorbidity: a population-based study. JAMA Dermatol. 2013;149:1173-1179.

4. Kerensky TA, Gottlieb AB, Yaniv S, Au SC. Etanercept: efficacy and safety for approved indications. Expert Opin Drug Saf. 2012:11:121-139.

5. Burmester GR, Panaccione R, Gordon, Mcllraith MJ, Lacerda APM. Adalimumab: long-term safety in 23,458 patients from global clinical trials in rheumatoid arthritis, juvenile idiopathic arthritis, ankylosing spondylitis, psoriatic arthritis, psoriasis and Crohn's disease. Ann Rheum Dis. 2013;72:517-524

6. Chaudhari U, Romano P, Mulcahy LD, Dooley LT, Baker DG, Gottlieb AB. Efficacy and safety of infliximab monotherapy for plaque-type psoriasis: a randomised trial. Lancet. 2001;357(9271):1842-1847.

7. Gottlieb AB, Cooper KD, McCormick TS, Toichi E, Everitt DE, Frederick B, et al. A phase 1, double-blind, placebo-controlled study evaluating single subcutaneous administrations of a human interleukin-12/23 monoclonal antibody in subjects with plaque psoriasis. Curr Med Res Opin. 2007;23:1081-1092.

8. Leonardi C, Matheson R, Zachariae C, Cameron G, Li L, Edson-Heredia E, et al. Anti-interleukin-17 monoclonal antibody ixekizumab in chronic plaque psoriasis. N Engl J Med. 2012;366:1190-1199.

9. Gottlieb AB, Blauvelt A, Thaçi D, Leonardi CL, Poulin Y, Drew J, et al. Certolizumab pegol for the treatment of chronic plaque psoriasis: results through 48 weeks from 2 phase 3 , multicenter, randomized, double-blinded, placebo-controlled studies (CIMPASI-1 and CIMPASI-2). J Am Acad Dermatol. 2018;79:302-314.e6. 
10. Reich K, Ortonne JP, Gottlieb AB, Terpstra IJ, Coteur G, Tasset C, et al. Successful treatment of moderate to severe plaque psoriasis with the PEGylated Fab' certolizumab pegol: results of a phase II randomized, placebo-controlled trial with a re-treatment extension. $\mathrm{Br} \mathrm{J}$ Dermatol. 2012;167:180-190.

11. Tan J, Bhambri S, Zeichner J. A practical approach to screening psoriasis patients for therapy with biologic agents. J Clin Aesthet Dermatol. 2008;1:50-54

12. Kaushik SB, Lebwohl MG. Psoriasis: which therapy for which patient: psoriasis comorbidities and preferred systemic agents. J Am Acad Dermatol. 2019;80:27-40

13. Menter A, Gottlieb A, Feldman SR, van Voorhees AS, Leonardi CL, Gordon KB, et al. Guidelines of care for the management of psoriasis and psoriatic arthritis: section 1. Overview of psoriasis and guidelines of care for the treatment of psoriasis with biologics. J Am Acad Dermatol. 2008:58:826-850.

14. Halverstam CP, Lebwohl M. Practical management and monitoring of psoriasis in patients on biologic therapy. Psoriasis Forum. 2007;13:4-12

15. Huang W, Cordoro KM, Taylor SL, Feldman SR. To test or not to test? An evidence-based assessment of the value of screening and monitoring tests when using systemic biologic agents to treat psoriasis. J Am Acad Dermatol. 2008;58:970-977.

16. Lebwohl M, Bagel J, Gelfand JM, Gladman D, Gordon KB, Hsu S, et al. From the Medical Board of the National Psoriasis Foundation: monitoring and vaccinations in patients treated with biologics for psoriasis. J Am Acad Dermatol. 2008:58:94-105.

17. Ganzetti G, Campanati A, Bernardini ML, Bettacchi A, Brandozzi G, Brisigotti $\mathrm{V}$, et al. The transitioning from conventional therapy to biological treatment in psoriatic patients: STRATOS, a project of Marche Region. G Ital Dermatol Venereol. 2016:151:340-346.

18. Mrowietz U, de Jong EM, Kragballe K, Langley R, Nast A, Puig L, et al. A consensus report on appropriate treatment optimization and transitioning in the management of moderate-to-severe plaque psoriasis. J Eur Acad Dermatol Venereol. 2014;28:438-453.

19. Ganzetti G, Campanati A, Bettacchi A, Brandozzi G, Brisigotti V, Bugatti $L$, et al. Switching from a biological therapy to another biologic agent in psoriatic patients: the experience of PsOMarche group. G Ital Dermatol Venereol. 2018;153:5-10.

20. Armstrong AW, Siegel MP, Bagel J, Boh EE, Buell M, Cooper KD, et al. From the Medical Board of the National Psoriasis Foundation: treatment targets for plaque psoriasis. J Am Acad Dermatol. 2017;76:290-298.

21. Menter A, Strober BE, Kaplan DH, Kivelevitch D, Prater EF, Stoff B, et al. Joint AAD-NPF guidelines of care for the management and treatment of psoriasis with biologics. J Am Acad Dermatol. 2019:80:1029-1072.

22. Smith CH, Jabbar-Lopez ZK, Yiu ZZ, Bale T, Burden AD, Coates LC et al. British Association of Dermatologists guidelines for biologic therapy for psoriasis 2017. Br J Dermatol. 2017;177:628-636.

23. Castaldo G, Galdo G, Rotondi-Aufiero F, Cereda E. Very low-calorie ketogenic diet may allow restoring response to systemic therapy in relapsing plaque psoriasis. Obes Res Clin Pract. 2016:10:348-352.

24. Barrea L, Balato N, Di Somma C, Macchia PE, Napolitano M Savanelli MC, et al. Nutrition and psoriasis: is there any association between the severity of the disease and adherence to the Mediterranean diet? J Transl Med. 2015:13:18.

25. Millsop JW, Bhatia BK, Debbaneh M, Koo J, Liao W. Diet and psoriasis, part III: role of nutritional supplements. J Am Acad Dermatol. 2014;71:561-569.

26. Armstrong AW, Bagel J, van Voorhees AS, Robertson AD, Yamauchi PS. Combining biologic therapies with other systemic treatments in psoriasis: evidence-based, best-practice recommendations from the Medical Board of the National Psoriasis Foundation. JAMA Dermatol. 2015;151:432-438.

27. Piaserico S, Cazzaniga S, Chimenti S, Giannetti A, Maccarone M, Picardo $M$, et al. Efficacy of switching between tumor necrosis factor-alfa inhibitors in psoriasis: results from the Italian Psocare registry. J Am Acad Dermatol. 2014;70:257-262.

28. Gordon KB, Gottlieb AB, Leonardi CL, Elewski BE, Wang A, Jahreis A, et al. Clinical response in psoriasis patients discontinued from and then reinitiated on etanercept therapy. J Dermatolog Treat. 2006;17:9-17.

29. Daudén E, Griffiths CE, Ortonne JP, Kragballe K, Molta CT, Robertson D, et al. Improvements in patient-reported outcomes in moderate-to-severe psoriasis patients receiving continuous or paused etanercept treatment over 54 weeks: the CRYSTEL study. J Eur Acad Dermatol Venereol. 2009;23:1374-1382

30. Gordon KB, Gottlieb AB, Langely RG, van de Kerkhof P, Belasco KT Sundaram $\mathrm{M}$, et al. Adalimumab retreatment successfully restores clinical response and health-related quality of life in patients with moderate to severe psoriasis who undergo therapy interruption. J Eur Acad Dermatol Venereol. 2015;29:767-776.

31. Landells I, Paller AS, Pariser D, Kricorian G, Foehl J, Molta C et al. Efficacy and safety of etanercept in children and adolescents aged $>$ or $=8$ years with severe plaque psoriasis. Eur J Dermatol. 2010;20:323-328.

32. Langley RG, Paller AS, Hebert AA, Creamer K, Weng HH, Jahreis A et al. Patient-reported outcomes in pediatric patients with psoriasis undergoing etanercept treatment: 12-week results from a phase III randomized controlled trial. J Am Acad Dermatol. 2011;64:64-70.
33. Sanclemente G, Murphy R, Contreras J, García H, Bonfill-Cosp X. Anti-TNF agents for paediatric psoriasis. Cochrane Database Syst Rev. 2015;2015:CD010017.

34. Klufas DM, Wald JM, Strober BE. Treatment of moderate to severe pediatric psoriasis: a retrospective case series. Pediatr Dermatol. 2016;33:142-149.

35. Ricceri F, Bardazzi F, Chiricozzi A, Dapavo P, Ferrara F, Mugheddu C, et al. Elderly psoriatic patients under biological therapies: an Italian experience. J Eur Acad Dermatol Venereol. 2019;33:143-146.

36. Schaufelberger BW, Horn E, Cather JC, Rahawi KW. Pregnancy outcomes in women exposed to ustekinumab in the psoriasis clinical development program. J Am Acad Dermatol. 2014;70:AB178.

37. Mariette $X$, Förger F, Abraham B, Flynn AD, Moltó A, Flipo RM, et al. Lack of placental transfer of certolizumab pegol during pregnancy: results from CRIB, a prospective, postmarketing, pharmacokinetic study. Ann Rheum Dis. 2018;77:228-233.

38. Clowse ME, Förger F, Hwang C, Thorp J, Dolhain RJ, van Tubergen A, et al. Minimal to no transfer of certolizumab pegol into breast milk: results from CRADLE, a prospective, postmarketing, multicentre, pharmacokinetic study. Ann Rheum Dis. 2017:76:1890-1896.

39. Flood KS, Porter ML, Kimball AB. Use of biologics in pregnancy: limitations stemming from clinical trials and registry experience. J Eur Acad Dermatol Venereol. 2019:33:e276-e277.

40. Porter ML, Lockwood SJ, Kimball AB. Update on biologic safety for patients with psoriasis during pregnancy. Int J Womens Dermatol. 2017;3:21-25.

41. Rosenbach M, Hsu S, Korman NJ, Lebwohl MG, Young M, Bebo BF Jr, et al. Treatment of erythrodermic psoriasis: from the medical board of the National Psoriasis Foundation. J Am Acad Dermatol. 2010;62:655-662.

42. Smolen JS, Landewé R, Bijlsma J, Burmester G, Chatzidionysiou K, Dougados $\mathrm{M}$, et al. EULAR recommendations for the management of rheumatoid arthritis with synthetic and biological disease-modifying antirheumatic drugs: 2016 update. Ann Rheum Dis. 2017;76:960-977.

43. Nakamura M, Abrouk M, Farahnik B, Zhu TH, Bhutani T. Psoriasis treatment in HIV-positive patients: a systematic review of systemic immunosuppressive therapies. Cutis. 2018;101:38;42-56.

44. Brunasso AM, Puntoni M, Gulia A, Massone C. Safety of anti-tumour necrosis factor agents in patients with chronic hepatitis C infection: a systematic review. Rheumatology (Oxford). 2011;50:1700-1711.

45. Di Lernia V. Treatment of psoriasis in patients with hepatitis $C$ virus infection. Clin Exp Dermatol. 2011;36:417.

46. Navarro R, Vilarrasa E, Herranz P, Puig L, Bordas X, Carrascosa JM, et al Safety and effectiveness of ustekinumab and antitumour necrosis factor therapy in patients with psoriasis and chronic viral hepatitis $\mathrm{B}$ or $\mathrm{C}$ : a retrospective, multicentre study in a clinical setting. Br J Dermatol. 2013:168:609-616.

47. Rokhsar C, Rabhan N, Cohen SR. Etanercept monotherapy for a patient with psoriasis, psoriatic arthritis, and concomitant hepatitis $\mathrm{C}$ infection. J Am Acad Dermatol. 2006:54:361-362.

48. Aslanidis S, Vassiliadis T, Pyrpasopoulou A, Douloumpakas I, Zamboulis C. Inhibition of TNFalpha does not induce viral reactivation in patients with chronic hepatitis C infection: two cases. Clin Rheumatol. 2007;26:261-264.

49. Salvi M, Macaluso L, Luci C, Mattozzi C, Paolino G, Aprea Y, et al. Safety and efficacy of anti-tumor necrosis factors $\alpha$ in patients with psoriasis and chronic hepatitis C. World J Clin Cases. 2016;4:49-55.

50. Dobler CC. Biologic agents and tuberculosis. Microbiol Spectr. 2016;4

51. Shobha V, Chandrashekara S, Rao V, Desai A, Jois R, Dharmanand BG, et al. Biologics and risk of tuberculosis in autoimmune rheumatic diseases: a real-world clinical experience from India. Int J Rheum Dis. 2019; 22.280-287.

52. Vilarrasa E, Puig L. Psoriasis: biologic treatment and liver disease. World J Dermatol. 2014;3:76-85.

53. Campanati A, Ganzetti G, Di Sario A, Damiani A, Sandroni L, Rosa L, et al. The effect of etanercept on hepatic fibrosis risk in patients with non-alcoholic fatty liver disease, metabolic syndrome, and psoriasis. J Gastroenterol. 2013;48:839-846.

54. Prussick R, Wu JJ, Armstrong AW, Siegel MP, Van Voorhees AS. Psoriasis in solid organ transplant patients: best practice recommendations from The Medical Board of the National Psoriasis Foundation. J Dermatolog Treat. 2018;29:329-333.

55. Galiano-Mejías S, Carretero G, Ferrandiz C, Vanaclocha F, Daudén E, Gómez-García FJ, et al. Manejo de los tratamientos biológicos en pacientes con psoriasis moderada-grave sometidos a intervenciones quirúrgicas en el registro español Biobadaderm. Actas Dermosifiliogr. 2017;108:52-58.

56. Larquey M, Girard C, Sbidian E, Richard MA, Aubin F, Schmutz JL. Efficacy of biologics in psoriasis patients under hemodialysis. Eur J Dermatol. 2017:27:531-533.

57. Peleva E, Exton LS, Kelley K, Kleyn CE, Mason KJ, Smith CH. Risk of cancer in patients with psoriasis on biological therapies: a systematic review. Br J Dermatol. 2018:178:103-113.

58. Chen Y, Friedman M, Liu G, Deodhar A, Chu CQ. Do tumor necrosis factor inhibitors increase cancer risk in patients with chronic immune-mediated inflammatory disorders? Cytokine. 2018;101:78-88.

59. Puig L. Obesity and psoriasis: body weight and body mass index influence the response to biological treatment. J Eur Acad Dermatol Venereol. $2011 ; 25: 1007-1011$ 